\title{
ASSESSING LABOUR STRENGTH IN SERBIA, CROATIA AND SLOVENIA: HOW TO EXPLAIN THE DIFFERENCES?
}

\author{
Nikola Kosovićc,*, Daria Copîl ${ }^{2}$ \\ ${ }^{1}$ Central European University, Department of Political Science \\ 9 Nador Street, Budapest, Hungary \\ ${ }^{2}$ Central European University, Department of Economics, \\ 9 Nador Street, Budapest, Hungary
}

\begin{abstract}
:
This paper assesses the current strength of labour unions in Serbia, Croatia and Slovenia and elaborates on the main factors that have led to the current situation. The first part of the paper includes an in-depth literature review of the current state-of-the-art in assessing the labour strength across Europe, with special emphasis on post-communist countries. The second part of the paper provides the assessment of labour union strength in the surveyed countries. The authors argue that there are significant differences in the roles of labour movements. Serbia and Slovenia quite differ, with extremely weak and extremely strong labour movements, respectively, while Croatia is located in between. Kosović and Copîl also elaborate on the causes of such weaknesses. They identify four main factors: communist legacy, nationalistic elites, economic crisis and foreign influence, and the lack of trust among citizens, and conclude that it is impossible to explain such a complex issue as labour strength by observing any of these factors separately. However, taken together, they all provide a quality explanation of the current union strength in the observed countries.
\end{abstract}

\section{Key words:}

Yugoslavia, labour unions, industrial relations, union strength, trust, Serbia, Croatia, Slovenia.

\section{INTRODUCTION AND METHODOLOGICAL ISSUES}

The issue of labour strength or weakness has been one of the most frequently discussed topics in contemporary works concerning industrial relations. This is especially the case in post-communist countries, where there is no agreement among scholars even on some of the most important issues. First of all, there are different opinions on whether the labour in post-communist countries is weak or strong. Secondly, there are various answers to the question what the point of reference is, to which labour power in post-communist countries should be compared. Finally, there are different explanations of the causes of labour union strength or weakness. All these questions will be addressed in this paper. We shall assess the strength of labour unions in Serbia, Croatia and Slovenia (SCS) and give convincing arguments on what caused their - as we argue - different strengths. 
The first point that needs to be addressed is the general assessment of labour strength in postcommunist countries. This issue is quite hard to tackle because, as Graeme Robertson puts in, "the hallmark of labour mobilization after democratization is variation, not uniformity" (Robertson, 2004 , p. 254). Therefore, there are various approaches that give different conclusions on labour power. Thus, although some authors might argue that labour unions were and still are strong in some cases (in Poland: Przeworski, 1991; Ekiert \& Kubik, 1998; Kubicek, 1999; in Slovenia: Bohle \& Greskovits, 2007; Grdešić, 2008; Šarić, 2014), there is abundance of literature that claims these countries to be merely exceptions from the general weakness (Greskovits, 1998; Meardi, 2000; Ost, 2000; Crowley \& Ost, 2001; Crowley, 2002, 2004; Stanojević et al., 2003; Bohle \& Greskovits, 2007; Crowley \& Stanojević, 2011). The key point here is the issue of how to measure labour strength. Indeed, if we observe the two most widely accepted measures of union strength - union density and collective bargaining coverage - we will see fairly low numbers in both terms in cases of almost all European post-communist countries (Table 1). However, since these numbers might be misleading in assessing the true power of labour unions in individual countries, there is a necessity for caseby-case studies. Since there is insufficient number of studies dealing with recent developments in SCS labour unions' power, this manuscript contributes to the literature in this filed.

Secondly, it is important to select the proper point of reference for assessing the union strength. We propose four possible approaches to assessing this issue in post-communist countries (we do this mostly for explanatory purposes and this idea does not exhaust all possibilities). First, as showed by Crowley (2004), it is possible to examine labour strength by comparing it to "the West", meaning to what would today be the EU members with no communist past, namely 17 countries in Northern, Southern and Western Europe. The second approach, which might be of biggest use for the cur- rent non-EU post-communist countries (Western Balkans and Eastern Europe), would be to select all $28 \mathrm{EU}$ members as a reference point. The third approach and the one that Bohle and Greskovits (2007) used in their work, is the interregional one. Thus, for instance, these authors used the sample of Visegrad countries, Baltic countries and Slovenia to show the differences among their labour unions. Finally, the approach used by several authors is the one that compares countries either on the basis of the common feature (accession to the EU in 2004: Aidukaite, 2011) or on an intraregional basis (Baltic states: Aidukaite, 2004, 2006; Post-Yugoslav area: Arandarenko, 2001; Stanojević, 2003; Grdešić, 2007, 2008, 2015; Crowley \& Stanojević, 2011). The latter approach will be used herein. We will refer to SCS labour unions' power in comparison to the post-Yugoslav area, mostly comparing them one to another.

Finally and most importantly for this study, there are various opinions on what influences labour strength in one country. Thus, Crowley (2004) has emphasized five possible explanations of strong labour unions in industrial relations literature: the strength of a country's corporatist institutions (Iankova, 2002), union competition (Ekiert \& Kubik, 1998), low levels of unemployment, existence of "exit" options (Greskovits, 1998), and - the factor that he considers most important and most influential - institutional and ideological legacies of communist times. He goes even further and argues that "nowhere is the impact of the communist legacy greater than on labour and trade unions" (Crowley, 2004, p. 420). Moreover, while writing about SCS, Stanojević (2003), Arandarenko (2001) and Grdešić (2008) add several more factors: elites' answers to workers' demands (Stanojević), ideologies (all authors), and economic crisis (Arandarenko). Finally, Bohle and Greskovits (2007) convincingly argue that not only did the initial political choices as a reaction to "both legacies of the past and their perception as either threats or assets from the viewpoint of national sovereignty and economic independence" matter, but also the "formative role of transnational and international influences as well 


\begin{tabular}{|c|c|c|c|c|}
\hline \multirow[t]{2}{*}{ Country } & \multicolumn{2}{|c|}{ Union density ${ }^{*}$} & \multirow{2}{*}{$\begin{array}{c}\text { Change in } \\
\text { union density }\end{array}$} & \multirow{2}{*}{$\begin{array}{c}\text { Collective bargaining } \\
\text { coverage }\end{array}$} \\
\hline & $1990 s$ & 2010 s & & \\
\hline Belarus & 96.1 & 90.5 & -5.6 & - \\
\hline Bulgaria & 51.4 & 20 & -31.4 & 18 \\
\hline Bosnia and Herzegovina & - & 30 & - & 100 \\
\hline Croatia & - & 40 & - & 55 \\
\hline Czech Republic & 36.3 & 17.3 & -19 & 40.9 \\
\hline Estonia & 62.1 & 6.9 & -55.2 & 25 \\
\hline Hungary & 62.5 & 14 & -48.5 & 33.5 \\
\hline Latvia & 28.3 & 11.6 & -16.7 & 20 \\
\hline Lithuania & 32.7 & 10 & -22.7 & 12 \\
\hline Macedonia & - & 28 & - & 100 \\
\hline Moldova & - & 26.8 & - & - \\
\hline Montenegro & - & 26 & - & 100 \\
\hline Poland & 27 & 13 & -14 & 28.9 \\
\hline Romania & 40.7 & 21.4 & -19.3 & 20 \\
\hline Russia & 74.8 & 37 & -37.8 & 70 \\
\hline Serbia & - & 19 & - & 60 \\
\hline Slovakia & 52.3 & 13.6 & -38.7 & 35 \\
\hline Slovenia & 66.5 & 23 & -43.5 & 92 \\
\hline Ukraine & - & 63 & - & - \\
\hline \multicolumn{5}{|l|}{ Intraregional average values } \\
\hline Post-Yugoslav area & & 27.6 & & 84.5 \\
\hline Visegrad countries & & 14.5 & & 34.6 \\
\hline Post-Soviet countries ${ }^{\star \star}$ & & 54.3 & & - \\
\hline Baltic countries & & 9.5 & & 19 \\
\hline Post-communist countries & & 26.4 & & 49.4 \\
\hline EU-28 & & 23 & & 62 \\
\hline $\mathrm{EU}-17^{\star * *}$ & & 35.7 & & 72.4 \\
\hline \multicolumn{5}{|c|}{$\begin{array}{l}\text { * Union density as the percentage of employees who are members of unions. } \\
\text { ** Excluding the Baltic region. } \\
\text { *** Excluding post-communist EU countries. }\end{array}$} \\
\hline
\end{tabular}

Table 1. Union density and collective bargaining coverage in post-communist countries Sources: Eurofound, International Labour Organization, ICTWSS database, worker-participation.eu, Federation of International Employers, national statistical units. Exact years of data vary in some cases. Some data in the table is missing. 
as their diversity" (p. 444). In the main part of our paper, we will use several of the above-mentioned factors. We argue that communist legacy, as proposed by several authors, is far from being enough to independently of other factors explain the cases of SCS. Instead, we provide arguments that apart from communist legacy, elites led by nationalistic ideologies, economic crisis and foreign influence also matter. Moreover, we argue that, to the best of our knowledge, most authors have neglected one important feature of labour unions that influences their strength - public trust or confidence. Finally, we also add to the current literature by going back further in the past and providing arguments that more objective causes led to the discrepancy in labour strengths. The main line of argumentation goes that the development of the three Yugoslav republics after the Second World War and, especially, during the 1990s, led to contemporary differences.

\section{ASSESSING THE STRENGTH OF SCS LABOUR UNIONS}

Although post-Yugoslav countries shared very similar paths of development during the second half of the twentieth century, their contemporary industrial relations differ significantly. Since many authors have already provided evidence that Serbian labour unions have played a minor role during the transition process (Upchurch, 2006b; Kohl, 2009; Mesman, 2012), we hereby focus more on their role in contemporary politics. Maybe this issue has been most concisely summarized in an interview with Branislav Čanak, the head of the second largest labour union in Serbia, United Branch Union "Independence" (UGS Nezavisnost). When asked about the union's influence on the government's economic policies, he stated: "No union has had any influence on the creation and implementation of economic policies of any government in Serbia over the last 20 years" (Novaković, 2011). One of the main reasons for this situation, at least according to Bernadette Segol from the European Trade Union Confederation, is political influence coming from the side of governmental elites in Serbia (Kojčić, 2014). This influence has resulted in fragmentation of trade unions and fake union pluralism (Ibid). Mihailović (2014) would add that labour unions themselves also bear a partial responsibility for their weakness. According to him, they lack strategies of development and union revival. Instead, the only strategy they have is "strategy of despair". Therefore, even if we employ Mihai Varga's (2013) ideas about observing labour unions' significance on a case-by-case basis and using "worker interest representation" as an indicator of labour strength, we would probably not get any good results. None of the three key elements of this concept - political autonomy of management's interests and influence, effectiveness in reaching workers' goals, and legitimacy of labour unions (p. 112-113) - would be satisfied in contemporary Serbian politics, as can be derived from previously mentioned sources.

The present labour unions in Croatia are often perceived as lacking both institutional and political influence. As is the case with the Serbian ones, they are often described as politicized, fragmented and powerless (Gabrić, 2014). The main consequence of such situation is an exclusive orientation of labour unions towards the state to solve their problems, even those that could be and should be solved on a bilateral basis between employees and the employer (Bagić, 2013). As stated by Krešimir Sever, the Head of the Independent Croatian Unions (NHS), the members of the unions are "frustrated by the lack of understanding in Croatia, and the common response of the workers and their families to a whole range of issues that concern them" (Gabrić, 2014). Moreover, he notices that this has been an ongoing trend for more than 15 years. Therefore, several other authors also convincingly argue that Croatian labour unions have more things in common with Serbian rather than with Slovenian unions. The main difference is that, like Serbian, "Croatian labour unions failed to secure a neocorporatist system of industrial relations as was the case in Slovenia" (Šarić, 2014, p. 34). 
Finally, Slovenian “(t)rade unions enjoy considerable public support, more than in Croatia or Serbia” (Grdešić, 2008, p. 139). Therefore, they have far more influence on political, economic and social situation in the society than the unions in the latter two countries. Although the membership in the main Slovenian labour unions has been diminishing (Stanojević, 2000), "strong union presence was successfully maintained" (Kohl, 2008, p. 3 ). Thus, one cannot be wrong to conclude that contemporary industrial relations in Slovenia are most highly developed unlike in Croatia and especially Serbia. Its labour unions are more capable of acting, they are more likely to obtain the desired outcomes, and, as such, have more labour strength than those in other two countries.

\section{CAUSES OF DIFFERENCES IN UNION POWER}

The question that arises from the previous discussion is related to possible causes of such differences. Many explanations have been suggested, but we do not consider any of them to be comprehensive enough. Some authors, like Stanojević (2003), ascribe these differences to discrepancy in elites' answers to workers' demands in the late 1980s. He argues that, while Slovenia chose "gradual market reform, conditioned by a strong respect for workers' interests" (p. 298), Serbia rejected all market reforms, which resulted in its transitional failure. On the other hand, Arandarenko (2001) stresses three key elements of the Serbian abortive transition: nationalism, the legacy of self-management, and economic crisis. Partly agreeing with both Stanojević and Arandarenko, Grdešić (2008) claims that the main reason for such serious differences between Slovenia, Croatia and Serbia could be different ideologies and practices of governing parties in these countries. We hereby discuss four key factors that contributed to this occurrence: communist legacy, nationalistic elites, economic crisis and foreign influence, and the lack of trust among the citizenships.
Probably the most widely spread argument about the weakness of labour unions not only in Serbia, but also across the whole Central and Eastern Europe (CEE) is the communist legacy argument. The roots of labour unions' weakness in SCS can be found in the legacy of Socialist Yugoslavia. While one can agree that this legacy was qualitatively different (i.e. better) from the Soviet one, it is hard to argue - although some authors do so (Stanojević, 2003; Grdešić, 2008) - that this legacy in any way played a positive role in development of contemporary labour unions in SCS.

The two key elements of the Yugoslav legacy are self-management and social ownership. The first one can be observed as the labour unions' or workers' "direct influence over political decision-making in labour-relevant areas and as the capacity to extract material rewards for workers" (Varga, 2013, p. 110), while the latter was intended to overcome the flaws of both private and state ownership - as seen by the communist elite - and bring about a more just, classless, society. Both key elements of Yugoslav legacy, self-management and social ownership, in our view, had merely and exclusively negative influence on workers representation organizations. First of all, self-management was only implemented on paper. Although the Workers Self-management Act, which prescribed significant independence of workers from the state (entitling the workers to even "make their own economic plans and determine their own salaries" (Zukin, 1975, p. 49), was adopted in 1950, it was never actually carried out (Liotta, 2001). Arandarenko (2001) confirms that, "(a)s in other socialist countries, the League of Communists (Yugoslav communist party) remained the ultimate and unchallenged arbiter in all important matters of social and economic life, including industrial relations" (p. 165). Finally, some authors argue that "in spite of the high claims for the selfmanagement system, the workers were not to be trusted to manage their own affairs. They were to be kept strictly under the control of the local party bureaucracy" (Gray, 2013, pp. 85-86). Moreover, 
many testimonies can be found such as those in Upchurch (2006a, pp. 5-6), in which people from contemporary perspective see self-management as negative for development of both Yugoslav economy and its democracy. Finally, we tend to agree with Arandarenko's views on the influence of selfmanagement on workers organizations. He argues that Yugoslav self-management system resulted in huge wage differentials, which prevented the emergence of class solidarity, as could be observed in Poland (Arandarenko, 2001). Moreover, it also led to fragmentation of labour unions, bringing the level of bargaining down to companies. Finally, as previously mentioned, "workers in the self-management system exercised no actual power even within their enterprises" (Ibid, p. 162).

One could also add that self-management in combination with social ownership negatively influenced the transition and privatization processes after the fall of communist regimes across former Yugoslav countries. An important thing to notice is that, in fact, there was never true, full social ownership in Yugoslavia. As testified by Hadžić (2002), "(o)fficially, social ownership has been defined as that belonging to the whole society - to everyone and to no one in particular. In practice, however, when an enterprise was profitable, profits were distributed to employees through wages, i.e. collective-type ownership, and when an enterprise was unprofitable, it asked the government for help, that is, state-type ownership" (p. 22). Due to personal attachments to the company and unwillingness to give away the power they had, no matter how small it was in reality, most workers preferred employee buyouts not only in Serbia, but also in Croatia, Bosnia and Herzegovina and Macedonia. Moreover, Hadžić (2002) argues that both of these factors significantly slowed down the privatization process in Serbia, since many worker councils were against privatization of their companies ( $p$. 18), most probably due to uncertainty about their future. The only exception in this regard was Slovenia, which nowadays has the strongest labour unions in this part of Europe. However, as noted by Bohle and Greskovits (2007), "the Slovenian economy was not only the most liberalized but also the most developed and western-oriented economy of former Yugoslavia and the whole Soviet bloc" (p. 452). This, among other factors, contributed to the success of its labour unions. On the other hand, apart from Slovenia to some extent, we conclude that the legacy of Socialist Yugoslavia had a negative influence on development of Serbian and Croatian industrial relations. This way, the legacies of former Yugoslavia to some extent help us to understand the differences among these three countries, but that is not sufficient to grasp the whole picture.

The second factor that, in our view, had a strong influence on contemporary differences in SCS labour union strengths were the ideologies that played the key role in the period from disintegration of Yugoslavia up to the end of the twentieth century. Since this argument has been discussed extensively (Arandarenko, 2001; Grdešić, 2006, 2008; Mesman, 2012; Tomičić, 2014), only the main points will be summarized herein. Grdešić rightly noticed that nationalism was the key ideological part of all parties during the early 1990s in Serbia, Croatia and Slovenia (Grdešić, 2008). However, since the democratic changes occurred in Slovenia much sooner than in Croatia or Serbia (1992 as compared to 2000), and pragmatic centrist elites in this country were more "willing to (...) accommodate workers' interests" (Ibid, p. 142), labour unions were given the opportunity to develop "cooperation and compromise on various sensitive issues" (Grdešić, 2006, p. 122). On the other hand, ideologies in Serbia and Croatia had a negative effect on development of industrial relations in these countries. A more direct influence of the Serbian elites on labour unions is thoroughly discussed in Mesman (2012), but the conclusion also applies to Croatia - the crucial element, which prevented internal organization reform of the unions and the establishment of new unionist practices, was authoritarian elite domination (p. 114). This dominance resulted in long-lasting conflicts 
between the elites and major labour unions and prevented wider membership in the workers movements, thus negatively influencing the strength of labour unions. This again testifies in favour of Slovenian labour unions having a far better starting position than their counterparts in Croatia and Serbia, which to a great extent enables providing explanation for the currently existing differences.

Thirdly, what cannot be neglected as one of the most important factors that contributed to differences among contemporary labour unions in SCS were different levels of economic development in these countries. Even during the Yugoslav period, Slovenia was by far the most developed republic, with a GDP per capita almost twice as big as the Serbian (179 to 94 index points with overall Yugoslavia $=100$ ), while Croatia was in-between the two with 117 index points (Lydall, 1989, p. 188). Moreover, when the disintegration of Yugoslavia began, Slovenia was strongly supported by the international community (the United States of America, International Monetary Fund, the World Bank and the European Community). Moreover, it did not have to develop war economy, as was the case with Croatia and especially Serbia, so it could focus more on raising the living standard of its citizens. Finally, as confirmed by Grdešić (2008), Slovenia was not a latecomer to financial reforms, as was the case with Serbia and Croatia, where in 2000 there was very little space "for the new centre-left and democratic governments to negotiate with the trade unions" (p. 143). All this implies that Slovenian government had enough space to manoeuvre in order to fulfil most of the Slovenian labour unions' demands, which resulted in their stability and more significant role than in any other postYugoslav country.

The situation in Serbia was completely different, because it was perceived as the troublemaker in the Balkans. Namely, it had no economic support from abroad (on the contrary, the sanctions imposed by the UN devastated the economy), and was at war during most of the 1990s. Since then, it is often said among the Serbian people that this country has been in permanent economic crisis. Starting from the sanctions imposed by the United Nations in 1992, followed by one of the most severe hyperinflations in world history (in December 1993, inflation amounted to the monthly level of $178.822 \%$ (Lovrić \& Palić, 2014)), to the NATO bombing in 1999, which devastated the Serbian infrastructure and economy, accompanied by transition and privatization failures, Serbia has become one of the least developed countries in Europe. Therefore, one of the causes of labour union weakness in Serbia comes from a more objective issue - inability of both government and private entrepreneurs to fulfil the demands of labour unions. Therefore, different governments' wishes to control the labour unions even nowadays - as they indeed mostly do - represent their mean of remaining in power. On the other hand, because of the high job insecurity and high unemployment rates, people and labour unions tend to put up with wage reductions and austerity measures more than expected. Therefore, apart from some smaller teacher unions, there was no serious reaction to the recent decision of the Serbian government to reduce pensions and wages in the public sector by $10 \%$. Ever since the fall of Milošević's regime till present days, the international financial institutions, mostly the World Bank and International Monetary Fund, have played a huge role in imposing these measures (Deacon \& Stubbs, 2007). However, these austerity measures have not shown much result. Serbian foreign debt and unemployment have been constantly rising, while inflation rates have been among the highest in the region (World Bank, 2015). Therefore, it seems reasonable to expect labour unions not to gain power in the near future, at least until the economic situation improves.

Lastly, the situation in Croatia was, as previously mentioned, somewhere between that in Serbia and Slovenia. As the latter country, Croatia was extensively supported by the international 
community both during and after the war, with the World Bank, International Monetary Fund and Germany playing the main role. Nevertheless, the civil war from 1991 to 1995 had a lot bigger negative influence on the Croatian economy than the ten-day one on the Slovenian. Thus, the level of development of Croatia was defined by these two key elements (the war and foreign financial aid), resulting in fairly good possibilities for the government to cooperate with labour unions, which eventually led to them having bigger strength than those in Serbia and less strength than the Slovenian ones.

Finally, the factor that many authors unjustifiably neglect when assessing the strength of workers representation organizations is the trust of general citizenship in the existing unions. Apart from Crowley (2004), who dedicated a few lines to this issue in general, to the best of our knowledge, no author has discussed this factor in terms of comparative labour strength. As Mihailović argues, "trust is, as well as reputation, the other side of social and political strength of labour unions. There is no trust in powerless unions, in unions that cannot do what they are supposed to do and what they had written in their programs, unions that are not what they present themselves to be, in unions that cannot do what they promise" (Stojiljković \& Mihailović, 2010). Therefore, we believe that public trust in labour unions in SCS is yet another factor that is contributing to differences in contemporary labour union strengths. As Table 2 shows, trust in labour unions in all three countries was practically the same right after the break-up of Yugoslavia. The numbers in it are the mean values, calculated based on the answers of people in the World Values Survey in 1995 and European Values Study in 2008 (the questions and methodology of the two studies were the same, which allows this kind of comparison). The answers were grouped into two categories, where 1 meant high trust in labour unions and 2 - low confidence in them.

\begin{tabular}{ccc}
\hline & \multicolumn{2}{c}{ Trust in labour unions } \\
\cline { 2 - 3 } & 1995 & 2008 \\
\hline Serbia & 1.76 & 1.87 \\
\hline Croatia & 1.76 & 1.82 \\
\hline Slovenia & 1.74 & 1.47 \\
\hline
\end{tabular}

Table 2. Trust in labour unions in Serbia, Croatia and Slovenia in 1995 and 2008

Source: World Values Survey (2015)

As can be seen, the confidence in labour unions in all three countries in 1995 was practically the same. However, in 2008, the difference between the countries was more than obvious. The trust of Serbian citizens has deteriorated from 1.76 to 1.87 , while the same trend could be observed in Croatia. Nevertheless, the change in the latter country is 0.05 points less than in the first one. On the other hand, Slovenian labour unions had a slightly better starting position, but its results in 2008 were more than impressive. The confidence in labour unions in this country grew over time, and reached the mean value of 1.47. This implies that Slovenia is practicaly the only of the three countries in which more people tend to trust labour unions than to have a negative attitude towards them.

The lack of trust in Croatia and Serbia has serious implications on the ability of labour unions in these countries to act. Low trust is in correlation with the negative perception that ordinary people have towards labour unions. Therefore, it is rather unlikely that general population will support any action conducted by labour unions, which would eventually lead to more satisfactory employers. This issue seems to be a vicious circle: while, on one hand, people do not trust labour unions, the latter are unable to act. On the other hand, without the popular support arising from the trust, labour unions cannot prove that they are to be trusted. Therefore, the question of trust needs to be perceived seriously. The unions in Serbia and Croatia need to come up with a strategy to regain people's trust, since only this will enable them to claim more institutional and political power. 


\section{CONCLUSION}

The main purpose of this paper was to assess the current strength of labour unions in SCS, as well as to explain the main factors that contributed to contemporary situation. The authors claim that labour unions in Serbia and Croatia are weak, while Slovenian unions assume significantly better positions in the society. We also provided several ideas on how to elaborate on the causes of such weakness. Although we tend to agree with Crowley that the communist legacy is an important factor, we argue that such an important question, as differences in labour strengths, cannot be explained relying solely on one point of view. If we accepted this argument, we would not be able to understand differences between labour unions' strength in SCS, since these countries all share the common past and similar development paths. Therefore, we argued that at least three more factors play significant roles: following Grdešićs (2008) and Arandarenko's (2001) ideas, we also considered worth mentioning different ideologies of the ruling elites in these countries during the 1990s. Moreover, by combining Arandarenko's (2001) views with part of the arguments provided by Bohle and Greskovits (2007), we suggested that the economic situation and different types of influences of international financial organizations and other countries also played an important role in the formation of contemporary differences. Finally, we contributed to the literature by providing an argument that public trust in Serbian and Croatian labour unions is indeed too low for them to have more serious institutional and political influence, while the Slovenian unions are more capable of doing so. The latter idea can be further developed by elaborating on the ways to overcome this lack of trust, but that might be the subject of some future research. Nevertheless, this paper has succeeded in its initial purpose, i.e. to comprehensively observe the issue of labour strength in SCS. It remains to be seen as to whether there will be any change in overcoming the flaws in labour unions' functioning in the future.

\section{REFERENCES}

Aidukaite, J. (2004). The emergence of the post-socialist welfare state: the case of the Baltic states: Estonia, Latvia and Lithuania. Huddinge: Södertörns högskola.

Aidukaite, J. (2006). The formation of social insurance institutions of the Baltic States in the post-socialist era. Journal of European Social Policy, 16(3), 259270. doi:10.1177/0958928706065597.

Aidukaite, J. (2011). Welfare reforms and socio-economic trends in the 10 new EU member states of Central and Eastern Europe. Communist and PostCommunist Studies, 44(3), 211-219. doi:10.1016/j. postcomstud.2011.07.005.

Arandarenko, M. (2001). Waiting for the workers: Explaining labor quiescence in Serbia. In: S. Crowley \& D. Ost (Eds.), Workers after Workers' States: Labor and Politics in Postcommunist Eastern Europe (pp. 159-180). Lanham, MD: Rowman and Littlefield.

Bagić, D. (2013). Neproduktivna ravnoteža moći: zašto nema kompromisa "socijalnih partnera" u Hrvatskoj $i$ zašto je malo vjerojatno da će ga uskoro biti. In: N. Vokić Pološki \& A. Obadić (Eds.), Zbornik radova okrugloga stola Uloga sindikata u suvremenome društvu (pp. 15-35). Zagreb: Ekonomski fakultet Sveučilišta u Zagrebu. In Croatian.

Bohle, D., \& Greskovits, B. (2007). Neoliberalism, embedded neoliberalism and neocorporatism: Towards transnational capitalism in Central-Eastern Europe. West European Politics, 30(3), 443-466. doi:10.1080/01402380701276287.

Crowley, S. (2002). Explaining Labor Quiescence in Post-Communist Europe: Historical Legacies and Comparative Perspective. Cambridge: Minda de Gunzburg Center for European Studies, Harvard University. Retrieved June 12, 2015, from http:// core.ac.uk/download/pdf/5081848.pdf.

Crowley, S. (2004). Explaining labor weakness in post-communist Europe: Historical legacies and comparative perspective. East European Politics \& Societies, 18(3), 394-429.

Crowley, S., \& Ost, D. (2001). Workers after workers' states: Labor and politics in postcommunist Eastern Europe. Lanham, MD: Rowman \& Littlefield.

Crowley, S., \& Stanojević, M. (2011). Varieties of capitalism, power resources, and historical legacies: explaining the Slovenian exception. Politics \& Society, 39(2), 268-295. doi:10.1177/0032329211405440. 
Deacon, B., \& Stubbs, P. (2007). Social Policy and International Interventions in South East Europe. Cheltenham: Edward Elgar Publishing.

Ekiert, G., \& Kubik, J. (1998). Contentious Politics in New Democracies: East Germany, Hungary, Poland, and Slovakia, 1989-1993. World Politics, 50(04), 547-581. doi:10.1017/S004388710000736X.

EVS. (2010). European Values Study 2008: Serbia (EVS 2008). GESIS Data Archive, Cologne. ZA4796 Data file Version 1.1.0, doi:10.4232/1.10186.

Gabrić, L. (2014). Što su nama danas sindikati: Subjektivan osjećaj nemoći mogao bi postati stvaran. Retrieved June 3, 2015, from http://www.lupiga.com/vijesti/ sto-su-nama-danas-sindikati-subjektivan-osjecajnemoci-mogao-bi-postati-stvaran. In Croatian.

Gray, C. (2013). What Caused the Yugoslav Economic Disaster? Vlaams Marxistisch Tijdschrift, 47(3), 84-89.

Grdešić, M. (2007). Tranzicija, Sindikati i Političke Elite u Sloveniji i Hrvatskoj. Politička Misao, 43(4), 121141. In Croatian.

Grdešić, M. (2008). Mapping the paths of the Yugoslav model: Labour strength and weakness in Slovenia, Croatia and Serbia. European Journal of Industrial Relations, 14(2), 133-151. doi:10.1177/0959680108089187.

Grdešić, M. (2015). Exceptionalism and its limits: The legacy of self-management in the former Yugoslavia. Retrieved September 15, 2015, from http://www. markogrdesic.com/uploads/3/1/8/0/31809299/exceptionalism.pdf.

Greskovits, B. (1998). The political economy of protest and patience: East European and Latin American transformations compared. Budapest: Central European University Press.

Hadžić, M. (2002). Rethinking Privatization in Serbia. Eastern European Economics, 40(6), 6-23. doi:10.1 080/00128775.2002.11041034.

Iankova, E.A. (2002). Eastern European capitalism in the making. Cambridge: Cambridge University Press.

Kohl, H. (2008). Where do Trade Unions stand today in Eastern Europe? Stock-taking after EU enlargement. Briefing Paper No. 5, 1-20.

Kohl, H. (2009). Social dialogue, workers' rights and freedom of association in the western Balkans-a survey after a first round of empirical research. SEER-South-East Europe Review for Labour and Social Affairs, (02), 151-173.
Kojčić, M. (2014). U Srbiji postoji lažni sindikalni pluralizam. Retrieved April 12, 2015, from http://www. danas.rs/danasrs/svet/globus/u_srbiji_postoji_lazni_sindikalni_pluralizam.12.html?news_id=293414. In Serbian.

Kubicek, P. (1999). Organized labor in postcommunist states: will the Western sun set on it, too? Comparative Politics, 83-102. doi:10.2307/422434.

Liotta, P.H. (2001). Dismembering the State: The Death of Yugoslavia and Why It Matters. Lanham, MD: Lexington Books.

Lovrić, I., \& Palić, A. (2014). Avramovićev dinar kao spas. Retrieved April 12, 2015, from http://www.novosti.rs/ vesti/naslovna/ekonomija/aktuelno.239.html:475107Avramovicev-dinar-kao-spas. In Serbian.

Lydall, H. (1989). Yugoslavia in Crisis. Oxford: Clarendon Press.

Meardi, G. (2000). Trade union activists, east and west: comparisons in multinational companies. Aldershot/ Burlington: Ashgate.

Mesman, T. (2012). Strategic Choices during System Change: Peak Level Unions and Their Struggles for Political Relevance In Post-Socialist Slovenia, Serbia and Poland. Unpublished doctoral dissertation, Central European University, Budapest, Hungary.

Mihailović, S. (2014). Moć i nemoć sindikata. Retrieved April 12, 2015, from http://sindikalizam. org/2014/10/19/moc-i-nemoc-sindikata/. In Serbian.

Novaković, G. (2011). Preživeli smo sa ogrebotinama. Retrieved April 12, 2015, from http://www.politika. rs/rubrike/Tema-nedelje/Moc-i-nemoc-sindikata/ Preziveli-smo-sa-ogrebotinama.lt.html. In Serbian.

Ost, D. (2000). Illusory corporatism in Eastern Europe: Neoliberal tripartism and postcommunist class identities. Politics \& Society, 28(4), 503-530. doi:10 $.1177 / 0032329200028004004$.

Przeworski, A. (1991). Democracy and the market: Political and economic reforms in Eastern Europe and Latin America. Cambridge: Cambridge University Press.

Robertson, G.B. (2004). Leading Labor: Unions, Politics, and Protest in New Democracies. Comparative Politics, 36(3), 253-272. doi:10.2307/4150130.

Šarić, I. (2014). Contemporary Theories of Political Economy and the Welfare State. Unpublished master thesis, Central European University, Budapest, Hungary.

Stanojević, M. (2000) Slovenian trade unions-the birth of labor organizations in post-communism. Družboslovne razprave, 16(32-33), 39-52. 
Stanojević, M. (2003). Workers' power in transition economies: the cases of Serbia and Slovenia. European Journal of Industrial Relations, 9(3), 283-301. doi:10.1177/0959680108089187.

Stojiljković, Z., \& Mihailović, S. (2010). Stanje socijalnog dijaloga u Srbiji posle dvadeset godina tranzicije. Beograd: SLA. In Serbian.

Tomičić, L. (2014). Sindikati devedesetih - strah, kalkuliranje i neiskorištene prilke. Retrieved 4 June, 2015, from http://stav.cenzura.hr/sindikati-devedesetihstrah-kalkuliranje-i-neiskoristene-prilike/. In Croatian.

Upchurch, M. (2006a). State, labour and market in post-revolution Serbia. Capital \& Class, 30(2), 1-30. doi:10.1177/030981680608900101.

Upchurch, M. (2006b). Strategic dilemmas for trade unions in transformation: the experience of Serbia. SEER-South-East Europe Review for Labour and Social Affairs, (04), 43-64.
Varga, M. (2013). Refocusing Studies of Post-Communist Trade Unions. European Journal of Industrial Relations, 19(2), 109-25. doi:10.1177/0959680113481735.

World Bank. (2015). Database on Serbia. Retrieved April 12, 2015, from http://data.worldbank.org/ country/serbia.

WVS. (2015). World Values Survey 1981-2014: Longitudinal Aggregate v.20150418. Retrieved 4 June, 2015, from http://www.worldvaluessurvey.org/ WVSDocumentationWVL.jsp

Zukin, S. (1975). Beyond Marx and Tito: Theory and Practice in Yugoslav Socialism. Cambridge: CUP Archive.

\section{PROCENA SNAGE RADNIČKIH SINDIKATA U SRBIJI, HRVATSKOJ I SLOVENIJI: KAKO OBJASNITI RAZLIKE IZMEĐU NJIH?}

\section{Rezime:}

U radu se ispituje uticaj radničkih sindikata u Srbiji, Sloveniji i Hrvatskoj, i ukazuje na glavne činioce koji su doveli do takve suituacije. Prvi deo rada obuhvata detaljan pregled literature o trenutnom stanju kada je reč o proceni snage radničkih sindikata širom Evrope, sa posebnim osvrtom na postkomunističke zemlje. U radu se vrši i procena uticaja radničkih sindikata u pomenute tri zemlje. Autori tvrde da postoje velike razlike u ulogama koji ovi sindikati imaju u tim zemljama. Naime, situacija u Srbiji i Sloveniji se drastično razlikuje, s obzirom da Srbija ima izrazito slabe, a Slovenija izrazito jake radničke pokrete, dok se Hrvatska nalazi negde između njih. Kosović i Copil nastoje da detaljnije obrazlože uzročnike slabog uticaja sindikata. Oni izdvajaju četiru glavna faktora: komunističko nasleđe, nacionalistički elitizam, ekonomsku krizu i strane uticaje, nedostatak poverenja među građanima, i na osnovu toga dolaze do zaključka da je nemoguće odgovoriti na tako složeno pitanje kao što je uticaj radničkih sindikata posmatrajući svaki činilac ponaosob. Međutim, gledano sve skupa, možemo doći do validnog objašnjenja o trenutnom stanju u radničkim sindikatima u posmatranim zemljama.

\section{Ključne reči:}

Jugoslavija, radnički sindikati, industrijski odnosi, snaga sindikata, poverenje, Srbija, Hrvatska, Slovenija. 